\title{
Application of carnauba-based wax maintains postharvest quality of 'Ortanique' tangor
}

\author{
Aplicação de cera de carnaúba mantém a qualidade pós-colheita do tangor 'Ortanique'
}

\author{
Francisca Ligia de Castro MACHADO ${ }^{1 \star}$, José Maria Correia COSTA ${ }^{1}$, Emanuele Nogueira BATISTA ${ }^{1}$
}

\begin{abstract}
This study aimed at evaluating compositional changes in the quality of 'Ortanique' tangor after coating with the carnauba-based waxes Aruá Tropical ${ }^{\circ}$ or Star Light ${ }^{\circ}$. The storage conditions studied simulated those of local marketing $\left(22 \pm 2{ }^{\circ} \mathrm{C}, 60 \pm 5 \% \mathrm{RH}\right)$. Non-destructive analysis, mass loss, peel color, and sensory evaluation, were performed upon coating and every three days up to the fifteenth day of storage. Destructive analysis, peel moisture content, chlorophyll of the peel, pulp color, juice content, soluble solids (SS), titratable acidity (TA), pH, and soluble solids to titratable acidity ratio, were performed upon coating and every four days up to the sixteenth day of storage. The assay was conducted using an entirely randomized design, with three replications (destructive analyses) or ten replications (non-destructive analyses), in a split plot scheme. Wax-coating, especially Aruá Tropical ${ }^{\circledR}$, maintained fruit freshness by reducing mass loss and peel dehydration and retaining green color. Peel moisture content, chlorophyll content, and juice content had lower rates in the wax coated fruits. Puncture force, soluble solids, titratable acidity, $\mathrm{pH}$, and soluble solids to titratable acidity ratio varied vary little over the course of storage. Sensory evaluation showed that the application of Aruá Tropical keeps 'Ortanique' tangor fresher for 6 days longer for commercialization.
\end{abstract}

Keywords: Citrus sinensis (L.) Osbeck x Citrus reticulata Blanco; moisture loss; visual quality; internal quality.

\section{Resumo}

Este trabalho objetivou determinar as mudanças na qualidade do tangor 'Ortanique’ após recobrimento com cera à base de carnaúba Aruá tropical ${ }^{\circ}$ ou 'Star Light ${ }^{\oplus}$. As condições de armazenamento assemelharam-se às condições de comercialização $\left(22 \pm 2{ }^{\circ} \mathrm{C}, 60 \pm 5 \% \mathrm{RH}\right)$. As avaliações não destrutivas, perda de massa, cor da casca e análise sensorial, foram realizadas logo após os recobrimentos e a cada três dias por quinze dias, enquanto as avaliações destrutivas, teor de umidade da casca, clorofila da casca, rendimento do suco, sólidos solúveis (SS), $\mathrm{pH}$, acidez titulável (AT) e SS/AT, foram realizadas logo após os recobrimentos e a cada quatro dias por dezesseis dias. O delineamento utilizado foi o inteiramente casualizado em esquema de parcelas subdivididas, com 3 repetições (avaliações destrutivas) ou dez repetições (avaliações não destrutivas). O recobrimento com cera de carnaúba, especialmente Aruá Tropical, foi efetivo na conservação da qualidade visual através da redução da perda de massa e desidratação e retenção da cor verde. O teor de água da casca, clorofila da casca e rendimento do suco decresceram a taxas menores nos frutos recobertos. A força de penetração, SS, AT, pH e relação SS/AT apresentaram pouquíssima variação durante o armazenamento. A análise sensorial mostrou que a aplicação de Aruá tropical proporcionou seis dias a mais para a comercialização dos frutos.

Palavras-chave: Citrus sinensis (L.) Osbeck $x$ Citrus reticulata Blanco; perda de umidade; qualidade visual; qualidade interna.

\section{Introduction}

Tangors are deliberate or accidental hybrids of the mandarin (Citrus reticulata) and the sweet orange (C. sinensis). MORTON (1987) describes 'Ortanique' tangor as oblate in form; having thin and adherent peel; pulp divided into 16 segments with scant rag, very juicy; seedless or with few seeds; and of distinctive acid-sweet flavor. Subject to bruising when freshly picked, tangors need careful handling by harvesters and packers, as well as appropriate conditions to extend fruit quality after harvest (BORGES; PIO, 2003). As a leading world citrus producer, Brazil contributes approximately $28 \%$ of the world citrus production (TAZIMA et al., 2009), and although recent data on citrus planted areas (INSTITUTO..., 2008) may indicate that citrus production has been emerging nationwide, tangor production is concentrated mostly in the south, and São Paulo state has the largest planted area. According to Borges and Pio, (2003) despite being much appreciated all over the country, the quality of tangors produced in traditional growing areas in Brazil is not comparable to that observed on fruits produced elsewhere.

Ceará state, located in the northeast Brazil, has been gaining attention as the most significant emerging fruit-growing state in the country. Fruit crops, such as pineapple, traditionally produced in the neighboring states, are now being regularly produced and exported on a large scale, while new crops are being planted. Among the newly planted fruit crops are citrus, including tangors, and initial production results have suggested that Ceará state may succeed as a major citrus producer. However, data on postharvest quality and storage of citrus, especially tangors, grown under local conditions are scarce or nonexistent.

Among the factors that most compromise quality of citrus during storage are dehydration caused by lost of moisture from the peel, fruit softening, and color degradation (SINGH;

${ }^{1}$ Food Science and Technology Department, Universidade Federal do Ceará - UFC, CP 12168, CEP 60021-970, Fortaleza, CE, Brazil, e-mail: ligiacmachado@yahoo.com ${ }^{*}$ Corresponding author 
REDDY, 2006). Coating treatments are known to maintain the quality of stored fruit crops by suppressing moisture loss, improving the strength of peel tissue and retaining volatile components, and controlling ripening by modifying $\mathrm{CO}_{2}$ and $\mathrm{O}_{2}$ concentrations inside the fruit (BALDWIN, 1994, 2003). Application of wax emulsion helped to maintain visual quality of citrus (PETRACEK; DOU; PAO, 1998), and more recently, carnauba-based wax decreased shell dehydration of 'Golden' pineapple by reducing moisture loss during storage (MACHADO et al., 2009).

This study aims at accessing the effects of coating with two carnauba-based waxes, Aruá Tropical ${ }^{\circledR}$ and Star Light ${ }^{\oplus}$, on the external quality and compositional changes of 'Ortanique' tangor from initial plantings in Ceara State, Brazil.

\section{Material and methods}

'Ortanique' tangor fruits ('Ortanique' scion grafted on 'Rough Lemon' rootstock) were harvested in the morning from plantings in Taboleiro de Russas, Limoeiro do Norte County ( $5^{\circ} 13^{\prime} \mathrm{S}$ and $\left.37^{\circ} 54^{\prime} \mathrm{E}\right)$, Ceará state, Brazil, transported by road to The Laboratory of Food Quality and Control, at Universidade Federal do Ceará, Fortaleza, Ceará State, and sorted for peel color, shape, size, and freedom from defects. Upon sorting, fruits were washed with water at room temperature, air-dried, and divided into three sets of 25 fruits each; ten fruits were used for non-destructive analyses and 15 fruits were used for destructive analyses over the course of storage. The first set underwent no treatment and served as the control; the second set was immersed in a carnauba-based wax Aruá Tropical ${ }^{\oplus}(18 \%$ soluble solids) emulsion, while the third set was immersed in a carnauba-based wax Star Light emulsion (11\% soluble solids). In both cases, the fruits remained immersed in the wax emulsion for at least 30 seconds. Both waxes were diluted with distilled water (1:1, v:v). Non-destructive analyses, mass loss and surface color, were carried out right after fruit coating and every three days up to the fifteenth day of storage $\left(22 \pm 2^{\circ} \mathrm{C}, 60 \pm 5 \% \mathrm{RH}\right)$, while the sensory evaluations were carried at the fifth, tenth, and fifteenth day of storage $\left(22 \pm 2^{\circ} \mathrm{C}, 60 \pm 5 \% \mathrm{RH}\right)$. Destructive analyses were carried out right after fruit coating and every four days up to the sixteenth day of storage and included puncture resistance, pulp color, peel moisture, chlorophyll content of the flavedo, juice content, soluble solids, titratable acidity, $\mathrm{pH}$, and SS to TA ratio.

Mass loss was determined by weighing each numbered fruit individually during storage and calculating mass loss in relation to fruit mass at harvest. The results were expressed as percentage (\%). Peel color was determined using a Minolta Chroma Meter (Minolta Corporation Instrument Systems) calibrated to a white porcelain reference plate. $L, a^{*}, b^{*}$ values were scored from the opposites sides of the fruit. The results were expressed as L, chroma and hue angle (McGUIRE, 1992). Peel moisture content was calculated on dry weight basis. Approximately $5 \mathrm{~g}$ of peel sample was weighed in an aluminum container and dried in hot air oven at $80^{\circ} \mathrm{C}$ for 24 hours.

Chlorophyll of the peel was extracted according to the methodology reported by Angel and Poggiani (1991) and expressed as mg. $100 \mathrm{~g}^{-1}$ flavedo.
Puncture resistance was assessed using a force gauge, model DD-200, fitted with a $5 \mathrm{~mm}$ cylindrical probe in the probe carrier. Tangor fruit was placed upon a flat plate with the stem calyx axis parallel to the surface of the plate. Puncture resistance, expressed as $\mathrm{N}$, was recorded as the maximum force required to puncture the fruit surface.

Juice content was calculated by weighing fruit juice and dividing it by fruit mass. The results were expressed as percentage (\%). Soluble solids (SS) were determined in juice samples taken from fruit halves, with a digital refractometer $\left(0-45^{\circ} \mathrm{Brix}\right)$ (Palette 100, Atago, Co., Ltd) and expressed as degree Brix. Acidity was determined by titration with $0.1 \mathrm{~N} \mathrm{NaOH}$, end point $\mathrm{pH}$ 8.2, and expressed as $\mathrm{mg}$ of citric acid. $100 \mathrm{~g}^{-1}$ juice; $\mathrm{pH}$ was measured with a $\mathrm{pH}$ meter directly in the juice.

Overall visual quality, surface color, and peel moisture were accessed visually by a panel of 30 untrained panelists, according to Meilgaard, Vance and Carr (2006). The panelists rated the intensity of the stimulus by making a mark on a $9 \mathrm{~cm}$, bipolar, horizontal line marked at the ends, which corresponded to the amount of the perceived stimulus. The left and the right ends of the scale corresponded to least and greatest levels, respectively.

The assay was conducted using an entirely randomized model in a split plot design. The main plot was coating treatment (non-coated control, coating with Aruá Tropical wax, coating with Star Light wax), while the subplots were six storage periods $(0,3,6,9,12$, and 15 days) for non-destructive analysis and five storage periods $(0,4,8,12$, and 16 days $)$ for destructive analysis. All data were subjected to analysis of variance (SISVAR 4.3). Tukey's test ( $\mathrm{p} \leq 0.05)$ was used to compare treatments classification when $F$ values were significant for main effects.

\section{Results and discussion}

A highly significant interaction between coating and storage period defined the changes in mass loss with coating reducing mass loss of 'Ortanique' tangor over the course of storage (Figure 1). Although both coatings were effective to reduce mass loss in comparison with uncoated fruits, Aruá Tropical coated fruits lost mass at lower rates than Star Light coated fruits. At the end of the storage period, Aruá Tropical coated fruits lost $16 \%$ of the initial mass, while Star Light coated fruits and control fruits lost approximately $20 \%$ each. The results observed for the control fruits in this study are comparable to those reported in a study by Singh and Reddy (2006), in which uncoated 'Nagpur Mandarin' orange stored for 18 days at ambient conditions $\left(28^{\circ} \mathrm{C}\right.$ and $\left.58 \% \mathrm{RH}\right)$ lost about $20 \%$ of their initial mass. The effectiveness of Aruá Tropical (18\%) wax in reducing mass loss during fruit storage has been reported by MACHADO et al. (2009), whose study showed that Aruá Tropical (18\%) coated pineapples showed lower rates of mass loss over the course of storage, as compared to uncoated pineapples.

Uncoated fruit peel became lighter as average luminosity values increased from 41, upon harvest, to 57, at the end of storage, while coated fruit presented smaller variation from harvest to the end of storage, 4.4 and 1.5 for Aruá Tropical and Star Light coated fruits, respectively (Figure 2). Changes in surface color, as measured by hue angle, was strongly influenced 


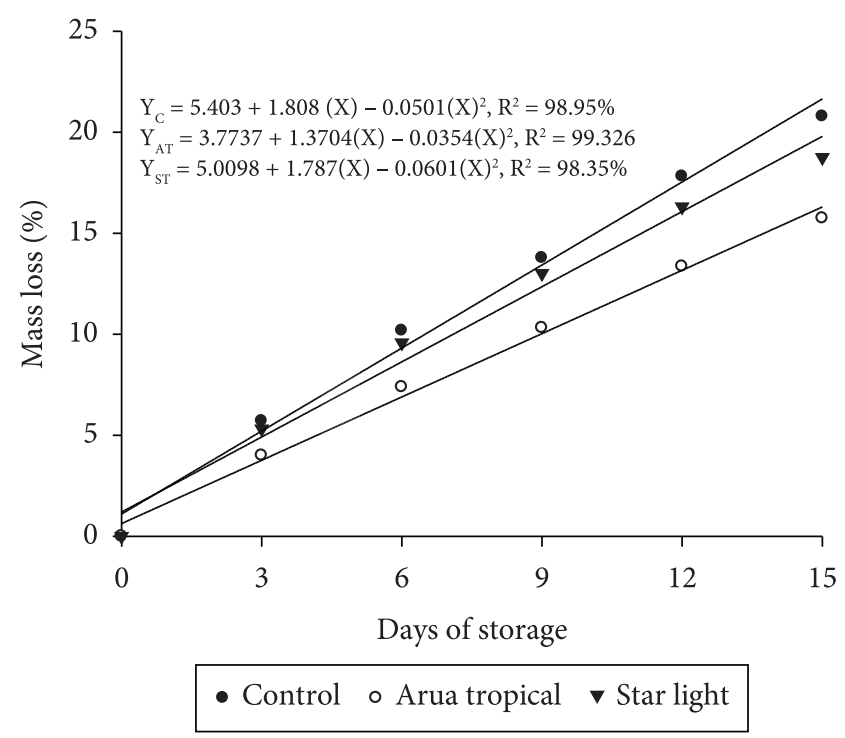

Figure 1. Mass loss (\%) of 'Ortanique' tangor uncoated or coated with carnauba-based wax Aruá Tropical or Star Light and stored at room temperature $\left(22 \pm 2{ }^{\circ} \mathrm{C}, 60 \pm 5 \% \mathrm{RH}\right)$ for 15 days.

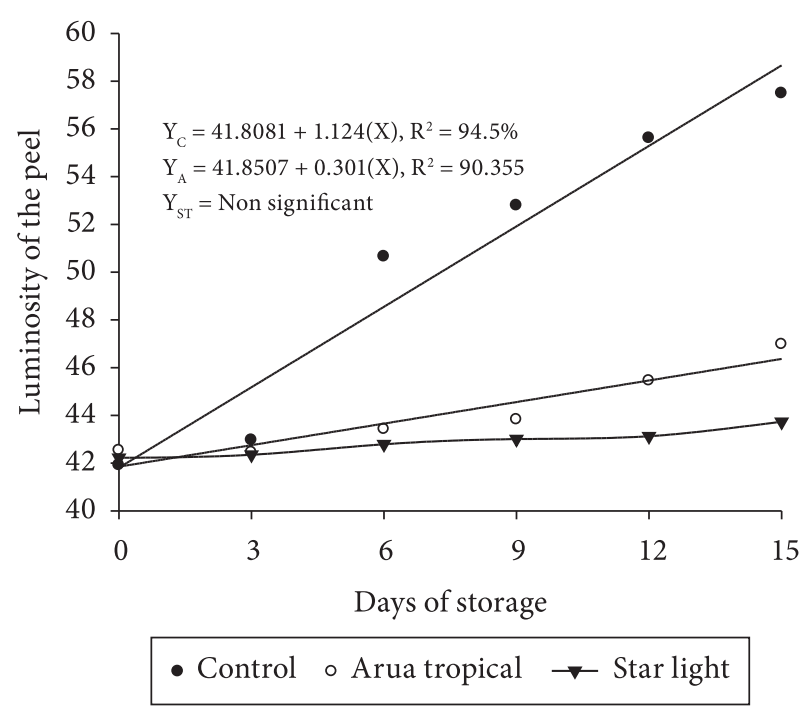

Figure 2. Peel luminosity of 'Ortanique' tangor uncoated and coated with carnauba-based wax, Aruá Tropical or Star Light and stored at room temperature $\left(22 \pm 2{ }^{\circ} \mathrm{C}, 60 \pm 5 \% \mathrm{RH}\right)$ for 15 days.

by the interaction between coating and storage periods and decreased following linear equations.

(Figure 3). Although the trends in color followed similar patterns for all treatments, uncoated fruits lost initial green color at higher rates, such that at the third day of storage some fruits had shades of yellow, turning completely yellow by the ninth day, while coated fruits preserved initial color for at least 9 days of storage.

Similar to hue angle results, a significant interaction between coating and storage period was also observed for peel chromaticity. Patterns of change in chroma, however, were

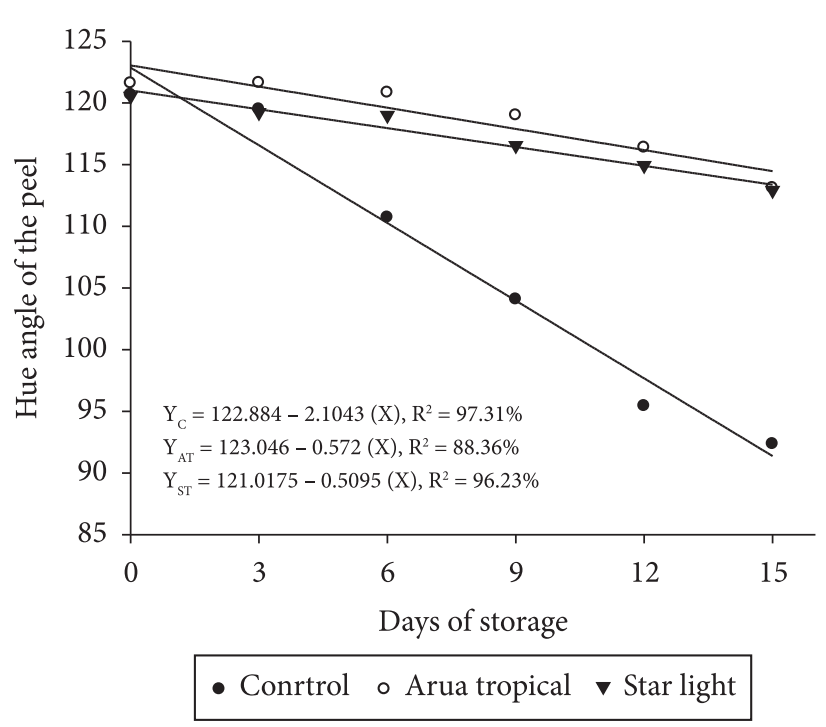

Figure 3. Hue angle of 'Ortanique' tangor uncoated and coated with carnauba-based wax, Aruá Tropical or Star Light and stored at room temperature $\left(22 \pm 2{ }^{\circ} \mathrm{C}, 60 \pm 5 \% \mathrm{RH}\right)$ for 15 days.

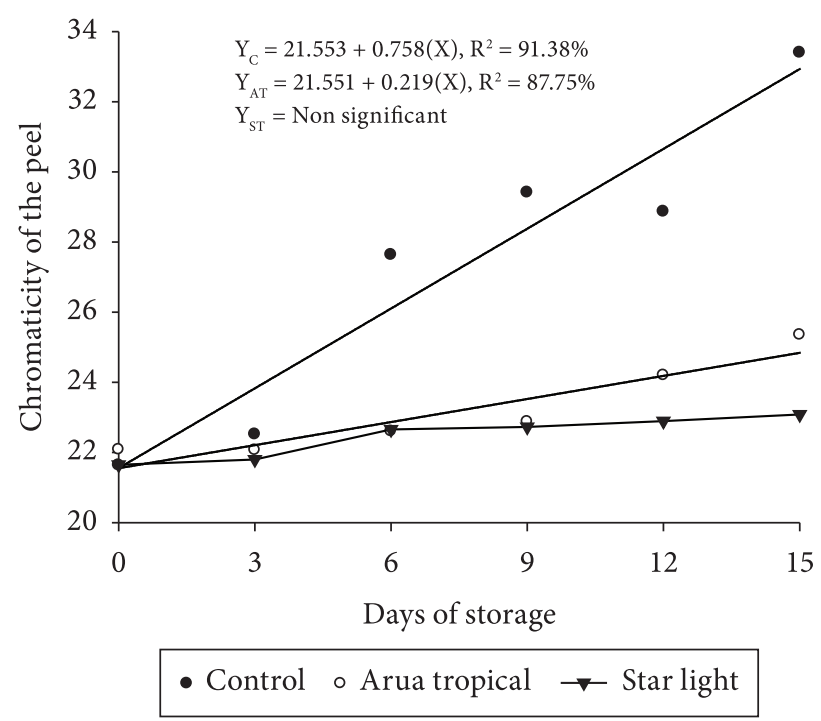

Figure 4. Chromaticity of 'Ortanique' tangor coated with carnaubabased wax, Aruá Tropical or Star Light and stored at room temperature $\left(22 \pm 2{ }^{\circ} \mathrm{C}, 60 \pm 5 \% \mathrm{RH}\right)$ for 15 days.

converse of those observed for hue angle as chroma values rose from harvest to the end of storage (Figure 4). Uncoated fruits also had the highest variation in chroma values, as compared to coated fruits. This increase in chroma may indicate that uncoated fruits become more pigmented over the course of storage.

Chlorophyll content of the flavedo was affected by treatments and storage periods, although independently. Overall, chlorophyll content decreased over the course of storage, and this decrease was strongly influenced by storage duration (Figure 5). Coated fruits had a significantly higher amount of chlorophyll than that of uncoated fruits, especially 
Aruá Tropical coated ones (Table 1), which corroborates the differences between hue angle levels observed for coated and uncoated fruits, presented above. These results are in agreement with those reported by Chen and Paull (1995), particularly when considering that loss of surface green color might be associated with the natural ripening process triggered by ethylene, which occurs as the result of chlorophyll molecule breakdown and parallel to an increase in carotenoids content. Therefore, application of wax delayed natural metabolic process that culminates with peel yellowing. Green color retention in citrus by application of coatings or coatings reagents was also reported by Yamauchi el al. (2008), whose studies report the inhibitory effect of sucrose laurate ester (SLE), a coating reagent, on the degreening of green Nagato-yuzukichi fruits after 20 days of storage at $20^{\circ} \mathrm{C}$. Similar to the findings reported above, the levels of chlorophyll content observed by Yamauchi et al. (2008) was converse of those reported for hue angle with SLE coated fruits having the lowest levels of hue angle and the highest chlorophyll content.

The moisture content of the peel accounted for $70 \%$ of the peel fresh weigh at harvest, but this percentage decreased to $61.5 \%$ at the end of storage following a linear equation (Figure 6). Although no significant difference was observed among treatments, Star Light coated fruits had the least moisture loss at the third day of storage. Thereafter, these fruits had a higher moisture loss than that observed for uncoated fruits and Aruá Tropical coated fruits, which showed the least moisture loss from the third day to the end of storage (Data not shown). It is well known that surface coatings block pores in the skin reducing permeance to water vapor and gases, which may reduce water loss (AMARANTE; BANKS, 2000). The intensity and/or permanence of the effect, however, may depend upon coating concentrations, among other factors (AMARANTE; BANKS; GANESH, 2001).

Although puncture force was affected by treatments and storage periods independently $(p<0.05)$, the average force required to puncture the peel of coated fruits did not differ from that of uncoated fruits (Table 1). It should be pointed out, however, that the lowest and the highest force required to puncture the peel of 'Ortanique' tangor was observed in fruits in which loss of moisture during storage were higher, Star Light coated fruits, and lower, Aruá Tropical coated fruits. The puncture force values observed in the present study are higher than those observed for 'Nagpur' Mandarin orange peel $(16.8 \pm 2.1)$ at harvest, as reported by Singh and Reddy (2006), suggesting that 'Ortanique' tangor had stronger peel than 'Nagpur' Mandarin orange. Regarding storage, puncture force increased slightly in terms of the number of days of storage following a linear equation $(\mathrm{Y}=52.04+0.71(\mathrm{x}))$, again, converse of loss of moisture from the peel.

The pulp was golden yellow, as indicated by hue angle values (approximately 84), and it was not affected by storage duration or coating (Table 1 ).

Juice content was affected by coating and storage duration, independently, and decreased approximately $7 \%$ from harvest to the end of storage $\left(\mathrm{Y}=32.78-0.533(\mathrm{x}), \mathrm{R}^{2}=73.9\right)$. With regard to treatments, juice content was significantly higher in Star Light coated fruits (30.8\%) than in Aruá coated fruits

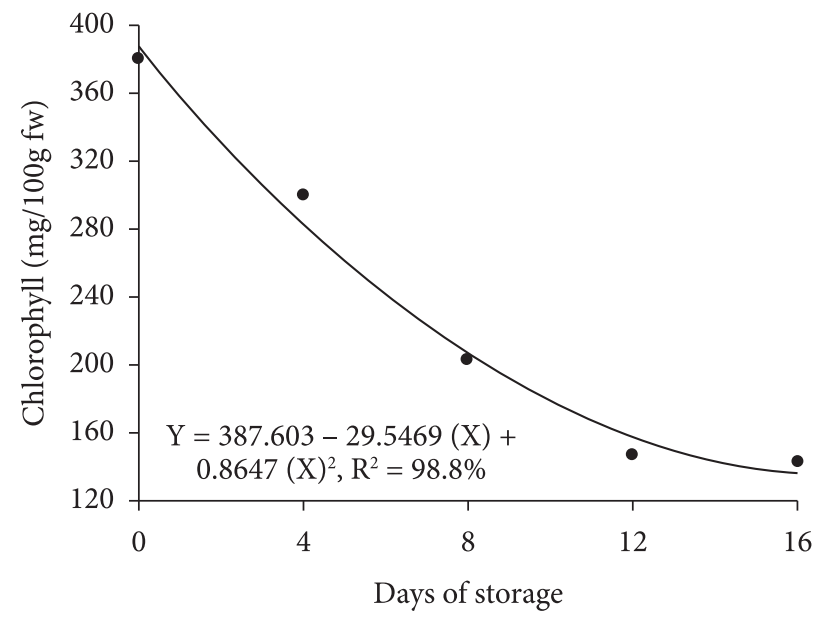

Figure 5. Chlorophyll content (mg. $100 \mathrm{~g}^{-1} \mathrm{fw}$ ) of 'Ortanique' tangor stored at room temperature $\left(22 \pm 2{ }^{\circ} \mathrm{C}, 60 \pm 5 \% \mathrm{RH}\right)$ for 16 days.

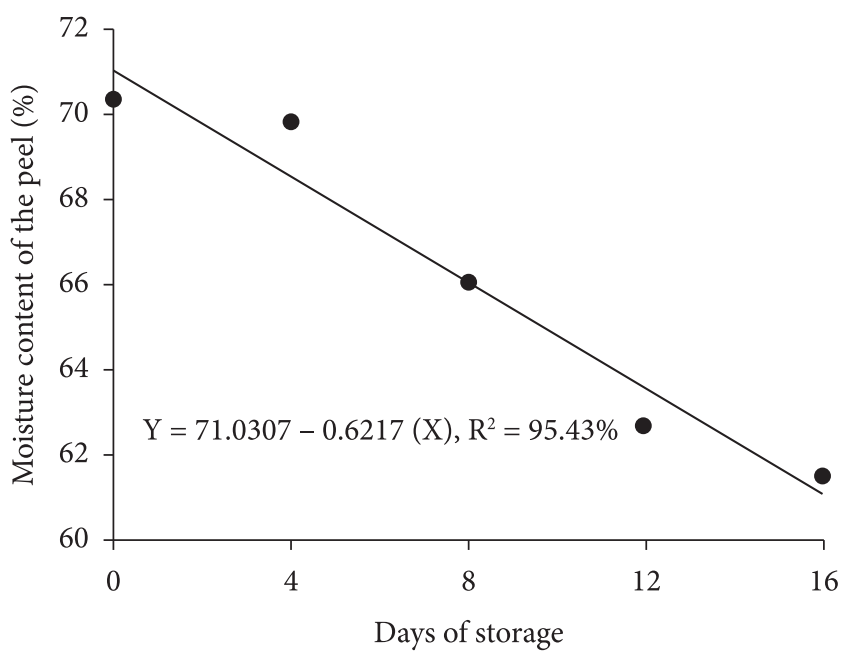

Figure 6. Moisture content (\%) of 'Ortanique' tangor stored at room temperature $\left(22 \pm 2{ }^{\circ} \mathrm{C}, 60 \pm 5 \% \mathrm{RH}\right)$ for 16 days.

(26.85\%) (Table 1). This difference, however, may not be of practical importance considering that the average values yielded by coated and uncoated fruits are very close. Taken as a whole, the percentage of juice, regardless of coating, observed in this study is lower than that reported by Borges and Pio (2003), $50.5 \%$ for 'Ortanique' grown in the south of the country. This difference between juice content might be due to many factors including climate and rootstock, which may play a direct role in fruit quality (McCOLLUN; BOWMAN, 2002).

Neither coating, nor storage duration influenced soluble solids content, titratableacidity, SS to TA ratio, and pH (Table 1). Alleoni, Jacomino and Rosa (2006), observed that whey protein coatings on oranges did not usually affect physical-chemical properties, but when it did, the differences among coated fruits and uncoated were very little.

Sensory evaluation was affected by coating since the average score given by the panelists showed significant difference on 
Table 1. Chlorophyll content (mg.100 $\mathrm{g}^{-1}$ flavedo), puncture force $(\mathrm{N})$, hue angle of the peel, juice content (\%), soluble solids (SS) $\left({ }^{\circ}\right.$ Brix), titratable acidity (TA) ( $\mathrm{mg}$ citric acid. $100 \mathrm{~g}^{-1}$ juice), and $\mathrm{pH}$ of 'Ortanique' tangor stored for 16 days at room temperature $\left(22 \pm 2{ }^{\circ} \mathrm{C}\right.$, $60 \pm 5 \% \mathrm{RH})$.

\begin{tabular}{|c|c|c|c|c|}
\hline Treatments & $\begin{array}{l}\text { Chlorophyll } \\
\left(\mathrm{mg} 100 \mathrm{~g}^{-1}\right)\end{array}$ & $\begin{array}{l}\text { Puncture } \\
\text { force }(\mathrm{N})\end{array}$ & $\begin{array}{l}\text { Hue angle } \\
\text { of the pulp }\end{array}$ & $\begin{array}{c}\text { Juice content } \\
(\%)\end{array}$ \\
\hline Control & $20.9^{\mathrm{a}}$ & $57.28^{\mathrm{a}}$ & $84.11^{\mathrm{a}}$ & $27.9^{\mathrm{ab}}$ \\
\hline Aruá Tropical & $24.1^{\mathrm{ab}}$ & $62.29^{\mathrm{a}}$ & $83.43^{\mathrm{a}}$ & $26.85^{\mathrm{a}}$ \\
\hline \multirow[t]{2}{*}{ Star Light } & $25.2^{\mathrm{b}}$ & $53.76^{\mathrm{a}}$ & $84.33^{\mathrm{a}}$ & $30.79^{b}$ \\
\hline & $\begin{array}{c}\text { SS } \\
\left({ }^{\circ} \text { Brix }\right)\end{array}$ & $\begin{array}{c}\text { TA } \\
\left(\mathrm{mg} .100 \mathrm{~g}^{-1}\right)\end{array}$ & SS/TA & $\mathrm{pH}$ \\
\hline Control & $8.72^{\mathrm{a}}$ & $0.55^{\mathrm{a}}$ & $15.98^{\mathrm{a}}$ & $3.89^{\mathrm{a}}$ \\
\hline Aruá Tropical & $8.27^{\mathrm{a}}$ & $0.52^{\mathrm{a}}$ & $16.21^{\mathrm{a}}$ & $4.03^{\mathrm{a}}$ \\
\hline Star Light & $8.34^{\mathrm{a}}$ & $0.55^{\mathrm{a}}$ & $15.41^{\mathrm{a}}$ & $3.96^{\mathrm{a}}$ \\
\hline
\end{tabular}

Values followed by different letter in the columns are significantly different at $\mathrm{p}=0.05$.

Table 2. Sensory evaluation of 'Ortanique' tangor coated with Aruá Tropical or Star Light wax and stored for 15 days at room temperature $\left(22 \pm 2{ }^{\circ} \mathrm{C}, 60 \pm 5 \% \mathrm{RH}\right)$.

\begin{tabular}{lccccc}
\hline \multirow{2}{*}{ Treatments } & \multicolumn{5}{c}{ Storage time (days) } \\
\cline { 2 - 6 } & 3 & 6 & 9 & 12 & 15 \\
\hline Control & $8.7^{\mathrm{a}}$ & $6.8^{\mathrm{b}}$ & $4.3^{\mathrm{c}}$ & $2.5^{\mathrm{b}}$ & $1.0^{\mathrm{c}}$ \\
Aruá Tropical & $8.8^{\mathrm{a}}$ & $8.4^{\mathrm{a}}$ & $7.7^{\mathrm{a}}$ & $6.6^{\mathrm{a}}$ & $5.5^{\mathrm{a}}$ \\
Star Light & $8.7^{\mathrm{a}}$ & $8.1^{\mathrm{a}}$ & $6.3^{\mathrm{b}}$ & $4.0^{\mathrm{c}}$ & $3.5^{\mathrm{b}}$ \\
\hline Control & $9.1^{\mathrm{a}}$ & $5.2^{\mathrm{b}}$ & $3.3^{\mathrm{b}}$ & $0.0^{\mathrm{b}}$ & $0.0^{\mathrm{b}}$ \\
Aruá Tropical & $9.2^{\mathrm{a}}$ & $9.0^{\mathrm{a}}$ & $8.0^{\mathrm{a}}$ & $7.4^{\mathrm{a}}$ & $7.0^{\mathrm{a}}$ \\
Star Light & $9.0^{\mathrm{a}}$ & $9.7^{\mathrm{a}}$ & $8.5^{\mathrm{a}}$ & $7.5^{\mathrm{a}}$ & $7.0^{\mathrm{a}}$ \\
\hline Control & $8.5^{\mathrm{a}}$ & $7.1^{\mathrm{b}}$ & $4.7^{\mathrm{b}}$ & $4.1^{\mathrm{b}}$ & $3.7^{\mathrm{b}}$ \\
Aruá Tropical & $8.0^{\mathrm{a}}$ & $8.3^{\mathrm{a}}$ & $7.1^{\mathrm{a}}$ & $6.2^{\mathrm{a}}$ & $6.1^{\mathrm{a}}$ \\
Star Light & $9.4^{\mathrm{a}}$ & $6.7^{\mathrm{b}}$ & $4.9^{\mathrm{b}}$ & $4.2^{\mathrm{b}}$ & $2.0^{\mathrm{b}}$ \\
\hline \multicolumn{5}{c}{$\mathrm{c}$}
\end{tabular}

Values followed by different letter in the columns are significantly different at $\mathrm{p}=0.05$.

the overall visual quality, surface green color, and moisture of the peel among the three treatments (Table 2). According to the panelists, uncoated tangors were yellow at the sixth day of storage, while Aruá Tropical and Star Light coated fruits remained green to the end of storage. It was also found that even though Star Light coated tangors remained green, they had shriveled and wrinkled peel, which compromised their overall visual quality, while Aruá Tropical coated tangors showed green, moistened peel toward the end of storage. These findings are in agreement with those reported above for mass loss, surface color, and peel moisture content.

\section{Conclusions}

- Coating 'Ortanique' tangor with Aruá Tropical extends market period for at least 6 days.

- Coating 'Ortanique' tangor with Aruá Tropical or Star Light reduces loss of green color and chlorophyll.
- Storage of 'Ortanique' tangor coated with Star Light emulsion may be a trade off between juice content and visual quality.

\section{Acknowledgements}

The authors are grateful to FrutaCor for supplying the tangor fruit and to Fundação Cearence de Apoio a Pesquisa FUNCAP for granting a scholarship to the first author. We also thank Gillen, A.M., PhD, for proofreading this manuscript.

\section{References}

ALLEONI, A. C. C.; JACOMINO, A. P.; ROSA, A. S. Recobrimento de laranja 'Pêra' com filme de concentrado protéico de soro de leite associado a plastificantes. Pesquisa Agropecuária Brasileira, v. 41 , n. 8 , p. 1221-1226, 2006. http://dx.doi.org/10.1590/S0100204X2006000800002

AMARANTE, C.; BANKS, N. H. Postharvest physiology and quality of coated fruits and vegetables. Horticultural Reviews, v. 26, p. 161-238, 2000.

AMARANTE, C.; BANKS, N. H.; GANESH, S. Effects of coating concentration, ripening stage, water status and fruit temperature on pear susceptibility to friction discolouration. Postharvest Biology and Technology, v. 21, p. 283-290, 2001. http://dx.doi.org/10.1016/ S0925-5214(00)00155-1

ANGEL, V. L.; POGGIANI, F. Estudo da concentração de clorofila nas folhas e seu aspecto de absorção de luz em função do sombreamento em mudas de quatro espécies florestais. Revista Brasileira de Fisiologia Vegetal, v. 3, n. 1, p. 39-45, 1991.

BALDWIN, E. A. Edible coatings for fresh fruits and vegetables: past, present, and future. In: KROCHTA, J. M. (Ed.). Edible coatings and Films to Improve Food Quality. Lancaster: Technomic, 1994. p. 25-64.

BALDWIN, E. A. Coatings and other supplemental treatments to maintain vegetable quality. In: BARTS, J. A.; BRECHT, J. K. (Eds.). Postharvest Physiology and Patology of Vegetables. New York: Marcel Dekker, 2003. p. 413-435.

BORGES, R. S.; PIO, R. M. Comparative study of the mandarin hybrid fruit characteristics: Nova, Murcot and Ortanique in Capão Bonito- SP, Brazil. Revista Brasileira de Fruticultura, v. 25 , n. 3, p. $448-452,2003$. http://dx.doi.org/10.1590/S010029452003000300022

CHEN, N. J.; PAULL, R. E. Effect of waxing and storage on pineapple fruit quality. In: INTERNATIONAL SYMPOSIUM ON POSTHARVEST SCIENCE AND TECHNOLOGY OF HORTICUlTURAL CROPS, 1995, Pequin, China. Proceedings... Pequin, 1995.

INSTITUTO BRASILEIRO DE GEOGRAFIA E ESTATÍSTICA - IBGE. Sidra, Citros. 2007. Disponível em: <http://www.ibge.gov.br>. Acesso em: 10 jan. 2010.

MACHADO, F. L. C. et al. Quality Maintenance of ripe pineapple as affected by application of wax associated to 1-Methylcyclopropene. Acta Horticulturae, v. 822, p. 261-268, 2009.

McCOLLUN, T. G.; BOWMAN, K. D. Effects of rootstock on fruit quality and postharvest behavior of 'Marsh' Grapefruit. Proceedings of the Florida State Horticultural Society, v. 115, p. 44-46, 2002. 
McGUIRE, R. G. Reporting of objective colour measurements. HortScience, v. 27, p. 1254-1255, 1992.

MEILGAARD, M.; VANCE, B. C.; CARR, T. Sensory evaluation techniques. 4. ed. CRC. Taylor and Francis Group, 2006. 294 p.

MORTON, J. Tangor. In: MORTON, J F. Fruits of warm climate. Miami, 1987. p. 145-146.

PETRACEK, D.; DOU, H.; PAO, S. The influence of applied waxes on postharvest physiological behavior and pitting of grapefruit. Postharvest Biology and Technology, v. 14, p. 99-106, 1998. http:// dx.doi.org/10.1016/S0925-5214(98)00018-0
SINGH, K. K.; REDDY, B. S. Post-harvest physico-mechanical properties of orange peel and fruit. Journal of Food Engineering, v. 73, p. 112-120, 2006. http://dx.doi.org/10.1016/j.jfoodeng.2005.01.010

TAZIMA, Z. H. et al. Produção e qualidade de frutos de cultivares de laranja-doce no norte do Paraná. Revista Brasileira de Fruticultura, v. 31, n. 2, p. 474-479, 2009. http://dx.doi.org/10.1590/ S0100-29452009000200022

YAMAUCHI, N. et al. Inhibitory effect of sucrose laurate ester on degreening in Citrus nagato-yuzukichi fruit during storage. Postharvest Biology and Technology, v. 47, p. 333-337, 2008. http:// dx.doi.org/10.1016/j.postharvbio.2007.08.003 